
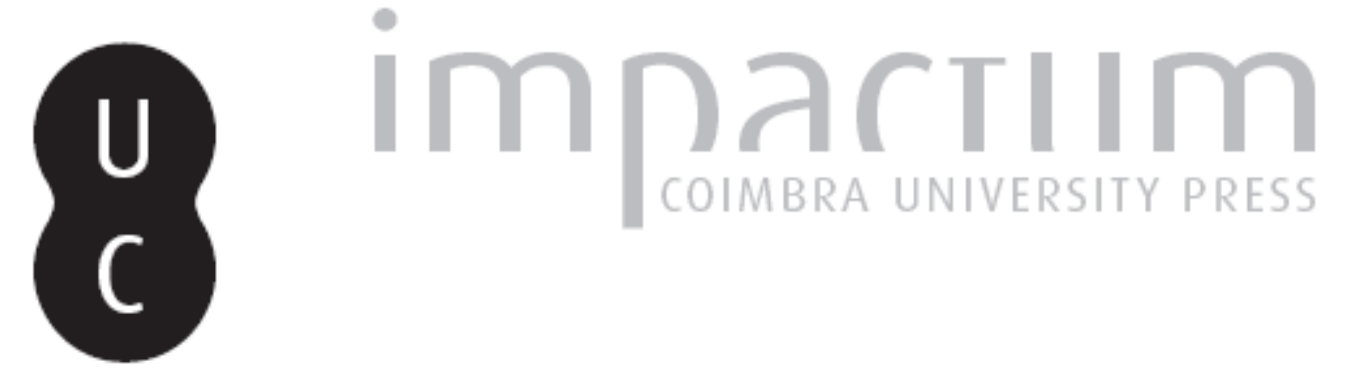

Sete contra Tebas de Ésquilo

Autor(es): $\quad$ Mota, Marcus, trad.

Publicado por: Annablume Clássica

URL persistente:

URI:http://hdl.handle.net/10316.2/24330

DOI:

DOI:http://dx.doi.org/10.14195/1984-249X_10_12

Accessed : $\quad$ 26-Apr-2023 15:08:42

A navegação consulta e descarregamento dos títulos inseridos nas Bibliotecas Digitais UC Digitalis, UC Pombalina e UC Impactum, pressupõem a aceitação plena e sem reservas dos Termos e Condições de Uso destas Bibliotecas Digitais, disponíveis em https://digitalis.uc.pt/pt-pt/termos.

Conforme exposto nos referidos Termos e Condições de Uso, o descarregamento de títulos de acesso restrito requer uma licença válida de autorização devendo o utilizador aceder ao(s) documento(s) a partir de um endereço de IP da instituição detentora da supramencionada licença.

Ao utilizador é apenas permitido o descarregamento para uso pessoal, pelo que o emprego do(s) título(s) descarregado(s) para outro fim, designadamente comercial, carece de autorização do respetivo autor ou editor da obra.

Na medida em que todas as obras da UC Digitalis se encontram protegidas pelo Código do Direito de Autor e Direitos Conexos e demais legislação aplicável, toda a cópia, parcial ou total, deste documento, nos casos em que é legalmente admitida, deverá conter ou fazer-se acompanhar por este aviso. 

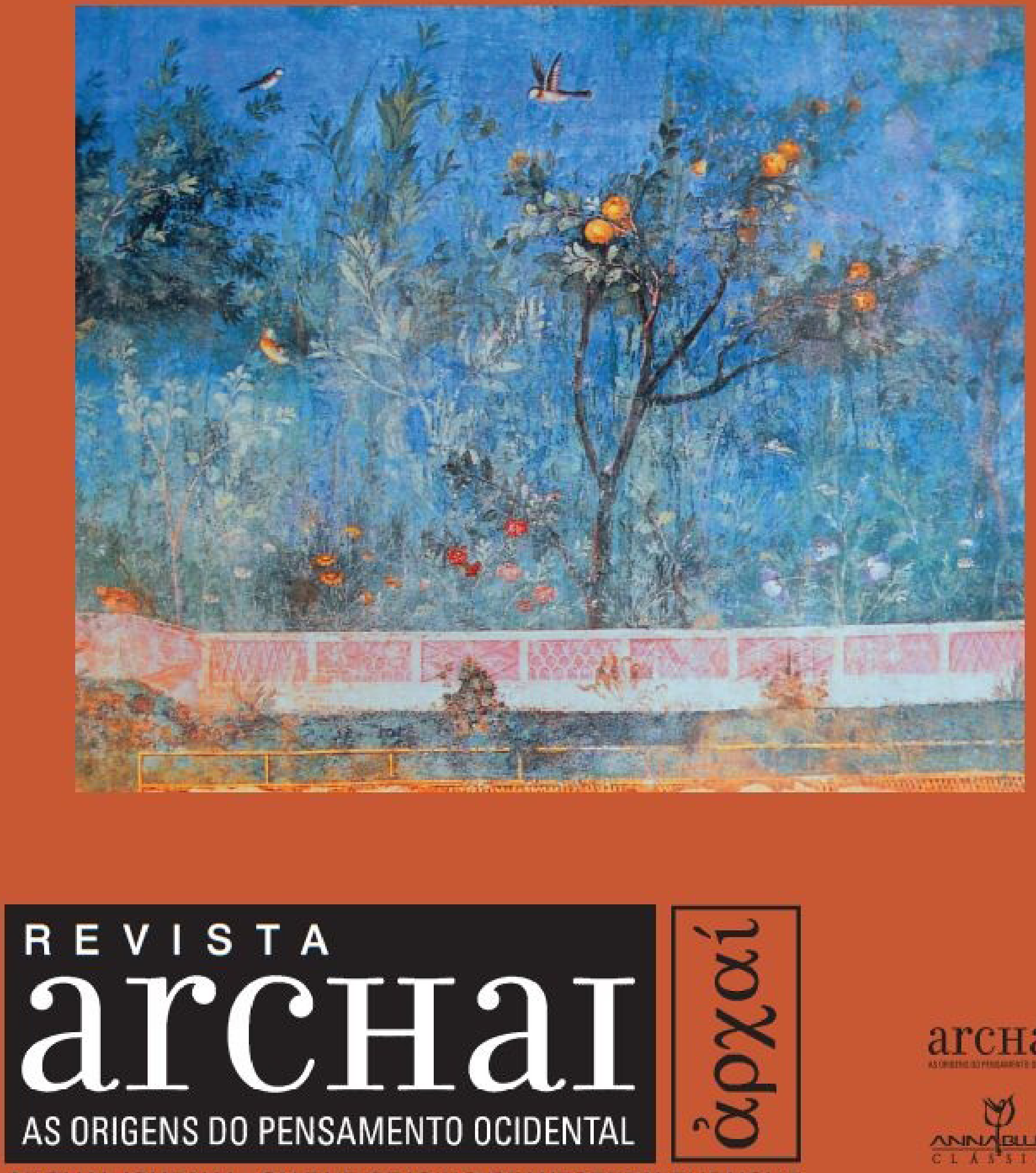

arcнаI

ARCHAI JOURNAL: ON THE ORIGINS OF WESTERN THOUGHT

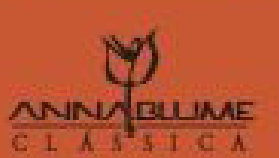




\section{SETE CONTRA TEBAS DE ÉSQUILO}

1. Universidade de Brasília. E-mail:marcusmotaunb@gmail. com / www.marcusmota.com.br
MOTA, M. (2013). Tradução de "Sete contra Tebas". Archai, n. 10, jan-jul, p. 145-168.
Tradutor: Marcus Mota

\section{Datas}

Sete contra Tebas é a última e única restante peça da vitoriosa tetralogia de Ésquilo apresentada no concurso dramático do festival das Grandes Dionísias em 467 a . C. em Atenas, tetralogia essa composta pelas tragédias Laio e Édipo e o drama satírico Esfinge.

Tal conjunto de peças conectadas, e principalmente a própria Sete contra Tebas, fez fama na Antigüidade, servindo tanto para modelo de composição, ao reafirmar o ciclo tebano como material básico para apropriação dramatúrgica (exemplo disso temos Antígona, Édipo Rei, e Édipo em Colono, de Sófocles e As suplicantes, As fenícias e As Bacantes, de Eurípides) quanto de paródia, como se vê em As fenícias, de Eurípides.

Na comédia As Rãs (405), Aristófanes coloca em cena Ésquilo defendendo-se das críticas de Eurípides: "eu compus um uma peça cheia de Ares (...) Os sete contra Tebas. Qualquer homem que tivesse assistido à peça desejava ser um guerreiro." Ésquilo vale-se da peça para reafirmar a superioridade de sua dramaturgia frente a de Eurípides.

Dentro produção teatral de Ésquilo Sete contra Tebas ocupa um privilegiado lugar como o das outras restantes cinco peças de aproximadamente 
90 compostas durante a vida do dramaturgo. Essa produção inicia-se com a primeira participação de Ésquilo nas competições dramáticas (499-496) A primeira vitória (atestada) nessas competições vem aproximadamente quinze anos depois (484). Dentro dessa sucessão de lapsos e pequenos pontos conhecidos temos

A) Os Persas (472) como exemplo de única peça de uma trilogia não conectada;

B) Sete contra Tebas (467), As suplicantes (década de 460) e as três peças da Orestéia, Agamenon, Coéforas e Eumênides, já como explorações de um encadeamento trilógico/tetralógico.

Então, cinco anos após Os Persas, Sete contra Tebas testemunha uma alteração nos parâmetros de composição, realização e recepção de espetáculos audiovisuais em Atenas. Novas tarefas para o dramaturgo e novas exigências do auditório vinculam-se na proposição de uma exibição de procedimentos que ultrapassem a unidade do evento teatral que a peça isolada parecia determinar. A tensão entre obra individual e a tetralogia proporciona a ampliação e diversificação da ficção representada, das expectativas da recepção e da forma de organização do que é mostrado.

Assim sendo, a leitura de Sete contra Tebas nos transforma em observadores de uma tradição de obras dramático-musicais já centenária ( em 534 Téspis havia vencido o primeiro concurso da Grande Dionísia) mas sujeita a modificações não só institucionais mas estéticas. Como primeiro documento de peças conectadas, Sete contra Tebas nos apresenta, tanto nos elementos selecionados para a exibição quanto na combinação e organização desses elementos, a complexidade audiovisual do espetáculo teatral ateniense e as dificuldades para sua elaboração e desempenho. As amplas dimensões da tetralogia, ainda mais representada em dias diferentes da competição, funcionavam como exibição mesma da competência do dramaturgo em conciliar a inteligibilidade do que é performando com o esforço de configurar uma situação de representação que integre tempos, espaços e desempenhos diversos.

Daí a forma de organização do espetáculo do qual o texto restante de Sete contra Tebas é roteiro de leitura e compreensão.

\section{A peça}

Dessa maneira, podemos contextualizar melhor a leitura da obra, concebendo o texto de Sete contra Tebas como roteiro de representação que demonstra as opções de Ésquilo no enfrentamento da concepção e realização de peças vinculadas formando uma tetralogia.

Concluindo a série de eventos cantados, dançados e falados em Laio e Édipo, Sete contra Tebas tanto retoma esses eventos quanto atualiza em cena o desastre final que se abate sobre a linhagem dos Labdácidas. A popular e bem conhecida maldição que atuava sobre essa linhagem encontra seu término, de forma que se explicita a correlação entre o encerramento da maldição e a conclusão das tragédias conjugadas antes do drama satírico Esfinge. Note-se a convergência de términos para Sete contra Tebas: ela é uma peça sobre fins, pois encerra uma seqüência de três tragédias, marcando no interior da tetralogia uma exaustão do tipo de espetáculo (tragédia) e seu nexo entre representação e audiência. Entre as peças anteriores e o drama satírico final, Sete contra Tebas promove uma dupla conclusão, seja da série de tragédias seja inaugurando a conclusão da trilogia mesma.

Em virtude disso assim distribuem-se as partes da peça e seus versos:

$$
\begin{aligned}
& \text { I - PRÓLOGO 1-77 } \\
& \text { II - PÁRODO (entrada coral)78-180 } \\
& \text { III - CENA EPIRREMÁTICA 181-286 } \\
& \text { IV - PRIMEIRO ESTÁSIMO(Atividade coral) }
\end{aligned}
$$

287-368

$$
\begin{aligned}
& \text { V - CENA DOS ESCUDOS 369- } 676 \\
& \text { VI - CENA EPIRREMÁTICA 677-719 } \\
& \text { VII - SEGUNDO ESTÁSIMO (Atividade coral) }
\end{aligned}
$$

720-791

VIII - TERCEIRO ESTÁSIMO(Atividade coral) 822- 860

IX - KOMMÓS(Lamentação) 875-1004.

Ou seja, abre-se o espetáculo de Sete contra Tebas com um conjunto de três blocos de fala (Etéocles, Espião, Etéocles) que constitui o prólogo da peça. 0 início da representação conecta-se à sua conclusão, a lamentação coral final onde o coro 
performa as mortes dos irmãos filhos de Édipo o quais, em mútuo assassínio, extinguem a amaldiçoada linhagem dos Labdácidas. A performance do prólogo falado desde já é projeção da lamentação final coral. Em um espetáculo de grandes dimensões, o desempenho atual é a configuração de sua inteligibilidade em relação à sua amplitude reconhecível.

Em seguida temos as parte corais II e VIII que se vinculam como performances isoladas corais centrando na orquestra, na área frontal à audiência, a exibição de desempenhos extremamente marcados, constituídos por específica coreografia e composição de ritmos e melodias.

Nesses momentos de exuberância aural, canta-se e dança-se para além dos eventos locais em Tebas: é a própria performance multimidiática do coro que se demonstra como único acontecimento exposto em cena, audível e visível como espetáculo dentro do espetáculo, de forma a reinterpretar o mundo de Tebas, ultrapassando-o. E nessa ultrapassagem o auditório mais do nunca entende que está em um teatro, compreendendo não só a trama dos fatos, mas observando os feitos audiovisuais que diante dele são exibidos. A performance atrativa de sons e figuras supera a identificação do enredo.

As partes III e IV são duplicadas nas partes VI e VII, formando partes espelhadas que gravitam em torno da enorme 'cena central'(V), a Cena dos escudos. Em III Etéocles tenta silenciar o coro; já em VI é o coro que tenta dissuadir Etéocles de lutar contra o irmão. Após esses encontros verbo-musicais (epirrema) onde um fala e o outro canta, segue-se sempre uma performance do coro (IV e VII), marcando o nexo e a inversão das partes duplicadas.

Desse forma, pode-se perceber como o espetáculo de Sete Contra Tebas é centrípeto, convergindo para a Cena dos escudos. Os módulos finais e mediais sobrepõem-se em volta do núcleo composto por uma série de sete blocos de falas e réplicas entre um mensageiro e Etéocles, blocos esses fechadas por breves e obliquas estrofes corais responsivas. A extrema organização e extensão dessa cena, disposta no relato dos inimigos de Tebas propostos pelo Mensageiro e dos campeões de Tebas postados por Etéocles, e na marcação emocional de fundo do coro, faz irrompe as largas estruturas de Sete Contra
Tebas e seu encaminhamento mesmo da amplitude de peças conectadas.

Ora, como grandezas podem ser quantificadas e a peça é escrita em versos, para melhor compreender amplitude da peça, temos a seguinte distribuição do número de versos cada parte: I. 78 versos, II. 103 versos, III. 106 versos; IV. 82; V. 308; VI. 42; VII. 72; VIII. 39; IX. 130. Tomando por base a magnitude da cena central, as extensões das outras partes se abreviam em várias proporções: IV/VI = 1/2; III/VII $=1 / 3 ; \mathrm{II} / \mathrm{VIII}=1 / 3$. Assim, a partir do centro, $\mathrm{a}$ relação entre as estruturas simétricas vai diminuindo na proporção de sua diferença de extensão. Nos extremos (I-IX), temos o reverso da situação que distribui maiores quantidades de versos na primeira parte, mas ainda prevalece a proporção 1/3. A manutenção dessa proporção acarreta tanto a correlação entre as estruturas em correspondência quanto o reconhecimento da construtividade do espetáculo na diferentes organizações de seus materiais.

Assim, o amplo escopo da representação que uma peça inserida em um ritmo tetralógico efetiva só se torna possível quanto maior for a resolução e correlação entre as partes que a compõe. A amplitude do espetáculo é proporcional à atividade multisetorial desenvolvida. Sete contra Tebas exibe-se pois como demonstração de uma dramaturgia que se confronta com os problemas de sua elaboração e desempenho.

\section{0 drama musical}

A multidão que se aglomerou para ver a peça em 467 a.C. , homóloga ao amplo escopo do espetáculo representado, não consumiu apenas elementos formais. A forma de organização do espetáculo era executada em cena através dos atos cantados e recitados dos atores e do coro. A diferença/oposição articulatória (canto/fala) posicionava a audiência frente à mudança de foco e de referência da movimentação dos atores e coro entre a orquestra, as entradas/saídas laterais e o fundo da cena. Falava-se e cantava-se em meio a um semicírculo de estátuas que atualizam as fronteiras de Tebas, como seus muros. Assim amuralhada, a cidade é percorrida pelos sons do cerco inimigo que confundem os espaços visível e não visível. 
No exíguo espaço visual frontal à recepção abatem-se gritos, choros, ruídos de carros de guerra, espadas, gargalhadas e gemidos, sinfonia de sons que completam as altissonantes e variadas atividades corais que durante a peça retomam, dentro da cidade, os confrontos iminentes e acontecidos (guerra de Tróia).

Ou seja, para fazer perdurar o impacto da autodestruição e ruína dos Labdácidas, Ésquilo transforma o espaço total que reúne os agentes dramáticos (coro e personagens) e o público em um espaço acústico no qual se desfigura e se recontextualiza a hegemônica perspectiva do soberano de Tebas. Etéocles, o que quer calar os outros, o que não quer ouvir, soçobra diante do cerco de sua cidade. Na medida em que seu mundo se fecha, o conhecimento da audiência se amplia. Como um personagem-escada, a sua continuada ignorância e surdez incrementa a participação da recepção no espetáculo.

Além desse comportamento antípoda à música do espetáculo que Etéocles realiza, temos a própria música do espetáculo que orienta a interação da audiência com os eventos performados. A forma de organização do desempenho do coro e os ritmos presentes na composição dos metros de sua atividade musical nos situam diante da amplitude aural do espetáculo.

0 terror quanto à invasão inimiga é performado na entrada do coro (párodo) na parte II , após um prólogo falado onde Etéocles procurava, já com retardo, responder às novidades trazidas pelo espia. A entrada coral é realizada sem organização estrófica e cantada através de metros dócmios - metros cuja tendência ao abatimento de uma uniformidade rítmica interpreta os extremos afetivos e referenciais da situação de cerco. Ao soerguer de um muro de palavras e ordens por parte de Etéocles, a desabalada carreira do coro para dentro de cena traz para dentro de cena os inimigos, figura a violenta invasão dos homens de Polinices.

As alterações nos metros do coro e na forma de organização de sua performance modulam proximidades e distâncias em relação às contracenações entre os agentes dramáticos bem como especificam as referências que constituem a memória do espetáculo.

Como o som executado ultrapassa seu momen- to de articulação, e esse som sempre é configurado metricamente em relação a um grupo de outros sons de metros específicos, quando há a retomada de alguma ocorrência sonora ocorre uma equação entre performances diversas em conjunto com a recontextualização da performance atual. Os dócmios da entrada coral atravessam o espetáculo de Sete contra Tebas, arrefecendo-se a partir do momento em que a figura de Etéocles perde sua hegemonia. A partir desse ponto há a predominância do lamento, de uma composição em iambos de exultante lamento, ironicamente vinculando-se ao drama satírico onde se atualiza a vitória sobre os tiranos.

\section{Tradução}

0 trabalho de tradução de Sete contra Tebas aqui exposto integra atividades do LADI (Laboratório de Dramaturgia e Imaginação Dramática ) bem como pesquisas relacionadas com meu doutorado. Em virtude disso procurei fornecer um texto limpo de notas, resolvendo as dúvidas mais globais nas rubricas mesmas.

Por essa razão, procurei não recair na armadilha de eruditizar o texto, igualando classicismo com vocabulário empedernido. 0s nomes próprios e de lugares, normalizados de acordo com Ureña Prieto e Pena, comparecem como paisagem sonora da obra. Em primeiro plano está a contracenação e os desempenhos vocais dos agentes dramáticos.

Segui o texto da edição de G.O.Hutchinson (HUTCHINSON 1985, confrontando-o em diversos momentos com a edição de M. West(WEST 1988). $\mathrm{Na}$ revisão desta tradução para a revista Archai, consultei a edição de A. Sommerstein (SOMMERSTEIN 2008).

Sendo Sete contra Tebas um drama em versos, mantive não só número de versos do original como também a ordem e posição de palavras-chaves e, disso, os mesmo padrões de interrupção e continuidade entre versos (enjambement). Não recriei os ritmos das partes faladas nem das partes cantadas. Antes, foi opção desta tradução trabalhar com a legibilidade do texto, de forma a promover uma leitura fluente que acompanhasse as modificações rítmicas e estruturais junto com as rubricas. 
Retomando as distribuições dos versos ( aspecto quantitativo da performance), pretendeu-se tornar compreensível o controle e a configuração dos atos dos agentes dramáticos em sua luta pela espaço de representação. Falar um maior ou menor número de versos é ocupar maior ou menor espaço. A quantificação dos desempenhos faculta-nos a espacialização do espetáculo e uma melhor apreensão de sua realização.

Dessa maneira, rompe-se com um hábito mentalista que opõe texto e espetáculo, hábito esse que promove a decorrente atenção apenas no dito, na explicação das referências descontextualizadas de seus procedimentos de efetivação teatral. Em virtude disso, grande parte das traduções transformam todo o texto em prosa, eliminando as diferenças indicadoras do contexto produtivo do espetáculo. Mas, na medida em que especificidade das grandezas é avistada, o verso efetiva a manipulação da duração das performances. 0 texto de Sete contra Tebas, a partir dos números atribuídos aos agentes dramáticos e às partes, converte-se em um roteiro de sua realização.

Já a recriação completa dos metros só poderia ser realizada em performance, a qual, por sua vez passaria pela pesquisa dos ritmos e de sua combinação na peça. Preferi atualizar os gestos fundamentais que os metros implicam, marcados pelo trato com as referências e pela sintaxe própria de cada gesto. Assim, nas partes faladas, temos tanto relatos quanto comandos para outros agentes dramáticos, mas acima de tudo temos uma continuidade vocal e performativa mais reconhecível, a qual se distingue das partes cantadas onde metáforas e coordenações rompem abruptamente com a manutenção de uma estabilidade de cena.

Dessa forma, a tradução aqui realizada situa-se entre a leitura e sua representação, como um convite para nos aproximarmos de uma escritura de espetáculos que mesmo após 2500 anos ainda se impõem diante de nós.

Em volta da orquestra, altar com estátuas de Zeus, Atena, Posidon, Ares, Afrodite, Apolo, Ártemis e Hera. 0 soberano de Tebas delibera com um pequeno grupo de cidadãos.

\section{ETÉOCLES}

1 Cidadãos de Tebas, quem quer que comande os negócios da cidade,

o leme na mão, os olhos abertos contra o sono,

precisa oportunamente dizer o que convém.

Pois, se agirmos bem, razão é Deus;

5 mas, ao contrário - que isso não aconteça! - e desgraças sobrevierem,

o nome Etéocles por muitos na cidade

será entoado desde já em louvores cheios de lamentos

pelas ruas. Que Zeus libertador

venha a ser celebrado na cidade de Tebas!

10 Vocês agora, seja quem mal deixou

o vigor da juventude ou quem já não é mais jovem, cada um de acordo com a idade que possui, no primor da vida e da força, o corpo inteiriço, precisa socorrer a cidade e os altares dos deuses 15 da terra, não se mostrando contrário a honrar a mãe terra doce nutriz de seus filhos.

Pois ela foi clemente quando os jovem se arrastavam pelo chão,

acolhendo todos eles, junto com suas misérias, revigorando-os como cidadãos armados de escudos,

20 homens fiéis sempre que for preciso .

Até o dia de hoje o deus tem nos favorecido.

Pois mesmo estando com as muralhas sitiadas há alguns dias

a cidade, graças aos deuses, tem se saído bem na guerra .

Mas agora fala o adivinho, pastor de aves 25 que, pelo ouvir e pela mente, sem uso do fogo, examina

presságios proféticos com técnica que nunca mentiu.

E assim fazendo esse mestre dos oráculos anuncia que um tremendo ataque aqueu contra nossa cidade para esta noite foi tramado. 30 Então para as muralhas e para os portais da fortaleza

rápido! Vamos, se armem todos dos pés à cabeça! Vigiem os parapeitos, ocupem os terraços

das torres, e nas saídas dos portais

permaneçam firmes, sem temer a quantidade

35 dos invasores reunidos! 0 deus vai fazer o melhor! 
Eu, de minha parte, enviei, às linhas inimigas, espias

e batedores, os quais creio não vão fracassar em seu retorno.

Tendo ouvido o que disserem não serei surpreendido por nada.

Sai o pequeno grupo de cidadãos por uma das entradas laterais. Entra apressado o ESPIÃO.

\section{ESPIÃ0}

Etéocles, valente senhor de Tebas,

40 venho lá do fronte trazendo a verdade.

Eu mesmo sou espia dos acontecimentos.

Pois sete homens, impetuosos comandantes,

sob um escudo negro degolaram um touro

e colocando as mãos no sangue do animal morto,

45 por Ares, Ênio e Fobos sanguinário,

juraram que ou vão destruir a cidade,

ferindo e saqueando Tebas com violência,

ou, se morrerem, vão regar a terra com seu sangue.

$E$ as lembranças dos parentes que ficaram em casa

50 derramando lágrimas arremessaram ao carro

de Adrasto, mas nenhum lamento havia em suas bocas.

Pois seus corações de ferro ardiam com valentia como os olhos de leões tomados por Ares.

E prova disso é que não se demoram temendo agir.

55 Quando os deixei disputavam, lançando a sorte - como

cada um deles conduziria seu exército contra as portas.

Então escolha depressa os mais bravos homens da cidade

e os posicione como comandantes nas saídas dos portais.

Pois já se aproxima o exército dos argivos completamente

60 armado, ergue pó da terra e os campos se mancham da

baba branca que goteja dos cavalos ofegantes.

Então vamos, como um atento piloto de barco

proteja a cidade antes que se desencadeie a tempestade

de Ares! Pois a onda de guerreiros retumba sobre a terra seca.

65 Decide logo o momento oportuno para fazer isso.

$\mathrm{Eu}$, de resto, vou manter vigilantes meus olhos

fiéis. E conhecendo, pois, através de um relato verdadeiro

o que acontece fora dos portais, o mal vai poder evitar.

\section{Sai o espião}

\section{ETÉOCLES}

Oh Zeus e Terra e deuses protetores da cidade, 70 e Maldição, poderosa Erínia de um pai, ao menos poupem , não arranquem com as raízes, toda destruída, feito despojo, a cidade que fala a língua da Hélade!

Impeçam que uma terra livre, que a cidade de Tebas

75 alguma dia possa cair em jugo de escravidão!

Sejam nossa ajuda! Creio que falo no interesse de ambas as partes,

pois uma cidade bem protegida venera suas divindades.

Sai Etéocles. Entrada (párodo) desorganizada do coro. Canto marcado pela perplexidade emotiva e contracenação entre o coro, as estátuas dos deuses e as referências extramuros.

\section{CORO}

Lamento meus medos e dores tão grandes!

Partiu o exército inimigo, deixando o acampamento. 80 Uma numerosa multidão de cavaleiros se espraia sobre nós.

A poeira que se ergue para o céu me faz ver uma mensagem sem voz, fiel e verdadeira.

Me apavoro com o estrondo de armas que aos gritos se aproxima da minha terra. 85 Volteja e ressoa, como indomável se abate tempestade nas encostas da montanha.

(Prece formal. Súplica.) IÓ, IÓ deuses e deusas, afastem

o mal que se lança sobre nós.

0 clamor dos guerreiros vem

90 sobre as muralhas. 
Uma multidão de escudeiros brancos avança

e gloriosa arremessa o passo contra a cidade.

(mais intenso) Quem vai nos livrar, qual deus ou deusa

vai nos proteger?

95 Vou mesmo tombar diante das

estátuas de nossos deuses?

(exclamação apelativa) Ah,

abençoados senhores!

É o momento de se unir às estátuas. Nós

devemos nos alongar em lamentos?

100 Ouvem ou não ouvem o estrondo dos escudos?

Quando, senão agora, vestes e coroas não iríamos ofertar

junto com nossas preces?

Eu vejo o estrondo. Não é ruído de uma simples espada.

0 que vai fazer, Ares? Vai abandonar

105 teus antigos domínios?

Oh deus do capacete dourado, olhe, olhe a cidade, que costumava considerar digna de teu favor!

Deuses protetores da cidade desta terra, venham, venham todos.

110 Vejam uma tropa

suplicante de virgens quanto à escravidão.

Em volta da cidade uma onda de homens de agitados penachos

115 quebra, soerguida pelo sopro de Ares.

Mas, Oh Zeus, pai todo poderoso,

afasta de nós completamente a conquista inimiga.

120 Pois os argivos cercaram a cidade de

Tebas. 0 temor de suas armas de guerra convulsiona.

Através das mandíbulas dos cavalos é certo que os freios ressoam a morte.

Sete homens destemidos que se distinguem do exército,

125 brandido a lança e em armadura, para as sete portas

avançam de acordo com resultado de sorteio.

E Palas, nascida de Zeus, soberana guerreira,

seja a salvação dessa cidade,

130 oh deusa! E o deus dos cavalos, senhor que reina sobre os mares

com seu tridente guerreiro, oh Posídon

nos liberte, nos liberte de nossos temores!

135 E tu Ares, (expressões de lamento) FÊU, FÊU, a cidade que traz o nome de Cadmo

guarde e faça visível teu parentesco com ela!

140 E Cípris, primeira mãe de nossa raça,

nos proteja, pois do teu sangue nós

viemos! Nos aproximamos de ti implorando

com súplicas e apelos aos deuses.

145 E Apolo, senhor dos lobos, torne-se um lobo para o exército inimigo,

ouvindo os gritos deles! $\mathrm{E}$, oh virgem filha de Leto, amada Ártemis

150 prepara teu arco!

\section{(Arranjo intracoral e canção estrófica)}

\section{Estrofe A}

\section{(Lamento)EÉ EÉ}

Ouço o ruído dos carros de combate em volta da cidade.

Oh veneranda senhora Hera!

Os eixos da roda rangem com o peso dos guerreiros. Amada Ártemis (lamento abrupto não formal)EÉ EÉ 155 Com o vibrar das lanças o ar se enfurece.

0 que nossa cidade está passando? 0 que vai acontecer?

E para onde ainda o deus vai nos conduzir?

\section{Antístrofe A}

\section{(Lamento responsivo) EÉ EÉ}

Uma saraivada de pedras de longe se arremete contra as nossas muralhas.

Oh amado Apolo!

1600 clangor dos escudos de bronze retine nos portais.

Escuta, oh filho de Zeus,

que tem sagrado poder de decidir a guerra durante os combates

e tu, Onca, abençoada senhora, em favor da cidade,

165 tua casa, defenda as sete portas.

\section{Estrofe B}

(Invocação final grandiloqüente e gestos de apelo)

Oh deuses todo poderosos,

oh, deuses e deusas capazes guardar 
as torres dessa cidade,

não abandonem a cidade que sucumbe pela lança 170 para um exército que fala outra língua!

Ouçam as virgens, ouçam totalmente

as súplicas oferecidas com os braços estendidos!

\section{Antístrofe B}

(Invocação responsiva)

Oh divindades amigas,

175 envolvam a cidade com libertação

mostrem como amam a cidade,

considerem as oferendas do povo,

e considerando, venham nos socorrer!

Tenham em vista, peço, nossa adoração

180 acompanhada de sacrifícios!

Entrada de Etéocles. Após a fala inicial do soberano, inicia-se um diálogo (diálogo epirremático) que alterna as falas de Etéocles e o canto do coro, ao qual, por sua vez, segue-se um debate verso a verso (esticomitia). Nesse enfrentamento de agora, Etéocles procura arrefecer a sonora presença do coro.

\section{ETÉOCLES}

A vocês eu pergunto, criaturas insuportáveis:

essa é a melhor coisa que deve ser feita para salvar a cidade?

Vai dar ânimo ao povo sitiado

185 lançar-se sobre as estátuas dos deuses protetores da cidade

com choros histéricos, o que os mais sensatos desprezam?

Nem em males ou em doce prosperidade possa ter vida em comum com o sexo feminino!

Pois participando do triunfo são de uma temeridade inaceitável,

190 mas tomadas de pavor são um mal para a casa e para a cidade.

Hoje mesmo entre os cidadãos essas correrias sem direção

produzem, pelo clamor das vozes, a apatia covarde.

Isso fortalece cada vez mais os que estão fora das muralhas

enquanto destruímos os que estão dentro para eles.
195 É o que se ganha vivendo com as mulheres!

Mas quem não ouvir meu comando,

homem, mulher ou qualquer um intermediário disso, contra eles vai ser deliberada sentença de punição.

E não vão escapar da sorte de apedrejamento popular.

200 Pois aos homens compete - as mulheres não participam disso -

o que é de fora da casa. Fiquem dentro e não causem maior dano.

Ouviram ou não ouviram: falo à gente surda?

(resposta do coro retomando a perplexidade emocional de sua entrada)

\section{Estrofe A}

CORO

Oh querido filho de Édipo, tremi ao ouvir

0 estrondo, estrondo do carro de combate

205 quando os eixos que move as rodas gemem

ou relincham os cavalos com o férreo freio na boca, sujeição que vem do fogo!

\section{ETÉOCLES}

0 que é isso? Acaso o homem fugindo da proa

à popa vai encontrar manobra salvadora

210 quando o barco sofre com as ondas do mar?

\section{Antístrofe A}

\section{CORO}

Mas eu, em correria, confiando nos deuses, lancei-

-me

sobre as antigas estátuas divinas logo que 0 estrondo

da avalanche destruidora se abateu em nossas portas.

É pois com pavor que alço minha prece em direção aos

215 divinos, para que possam exceder em cuidado para com a cidade.

\section{ETÉOCLES}

Vocês suplicam que as muralhas afastem a lança inimiga.

0s deuses vão mesmo acorrer a estas súplicas? Mas quando 
uma cidade é capturada dizem que os deuses a abandonaram.

CORO

\section{Estrofe B}

(reação veemente)

Que em minha vida jamais possa ser abandonada pelos deuses

220 aqui reunidos, nem que possa acontecer de ver a cidade inteira sendo percorrida por soldados que a devastam com chamas devoradoras!

ETÉOCLES

Não se inclinem a invocar os deuses de modo tão vil. Pois a obediência é mãe das ações bem sucedidas, 225 oh mulher, é salvação. É o que prevalece.

CORO

\section{Antístrofe B}

Claro que é . Mas o poder divino está acima de tudo.

Muitas vezes em desgraças o homem, perplexo,

sofre duramente, com os olhos enuviados, quando, de repente, as aflições são resolvidas.

\section{ETÉOCLES}

230 Aos homens é assim, vítimas e sacrifícios

fazer aos deuses e examinar as estratégias dos inimigos;

e, em troca, a ti cabe o silêncio e ficar dentro da casa.

CORO

\section{Estrofe C}

Pelos deuses moramos em uma cidade inabalável, muralha que protege contra as hordas inimigas

235 Quem aqui teme a retribuição divina?

ETÉOCLES

Certamente não nego teu direito de honrar as divindades da casa,

mas não infunda um coração covarde nos cidadãos, não se mova, nem se deixe aterrorizar em demasia.

\section{Antístrofe C}

Ouvindo agora novos estrondos

240 espantada de medo para a acrópole, morada veneranda, corri.

\section{ETÉOCLES}

Então, ao tomar conhecimento dos mortos e feridos, não acolha as novas com lamentos.

Pois Ares se alimenta disso, de homens mortos.

Debate e confrontação dramática (esticomitia)

CORO

245 Pois agora eu ouço bem o relincho dos cavalos! ETÉOCLES

Sequer está ouvindo agora o que claramente ouve tanto.

CORO

Geme a cidade desde o fundo da terra ao se ver cercada!

\section{ETÉOCLES}

Não há nada suficiente para deliberar assim sobre estas coisas.

CORO

Tenho medo. Cresce o som dos golpes sobre as nossas portas.

\section{ETÉOCLES}

250 Nem com isso se cala em correria através da cidade?

CORO

Oh deuses aqui reunidos, não abandonem nossas muralhas.

\section{ETÉOCLES}

Desgraça! Não consegue se manter calada?!

CORO

Deuses da cidade, que a escravidão por sorte não seja o meu fim!

ETÉOCLES

Você mesma é que lança para escravidão a mim $e$ toda a cidade.

CORO

250 Oh Zeus todo poderoso, tuas setas volte contra 
os inimigos!

ETÉOCLES

Ah Zeus, como foi capaz de nos dar por companhia a mulher e sua raça!

CORO

Alguém tão miserável, como o homem, quando a cidade é tomada.

\section{ETÉOCLES}

Continua falando, querendo o favor das estátuas? CORO

Sem mais coragem o medo se apoderou de minha língua.

ETÉOCLES

260 Suplico que de pronto possa fazer algo solene para mim.

CORO

Fale depressa e depressa vou saber cumprir. ETÉOCLES

Cale-se, oh infeliz, não atemorize os nossos! CORO

Eu me calo. Minha sorte será a sorte de todos.

\section{ETÉOCLES}

Prefiro mais isso em lugar do que você falou antes.

265 E outra coisa digo, deixe essas estátuas dos deuses

e ora pelo melhor que se pode querer: que os deuses entrem na guerra conosco.

E ouvindo minhas preces, em seguida cante

o hino da vitória, clamor sagrado e propício, costume da Hélade que saúda sacrifícios,

270 isso traz confiança aos nossos e dissipa o medo ao inimigo.

Eu, aos deuses protetores de nossa cidade ,

os que guardam as terras e vigiam a assembléia,

e às fontes de Dirce e às águas do Ismeno, declaro que, se tudo terminar bem e a cidade for salva,

275 sangue de ovelhas vai jorrar no altar dos deuses,

para celebrar a vitória.

Despojos dos inimigos feridos pela lança

vou dedicar aos templos sagrados.

Faça desse modo os votos aos deuses, sem esses gemidos habituais,

280 inútil e estúpido pranto ofegante.

Pois não há escapatória ao que é destinado aos mortais.

Eu mesmo sete homens contando comigo vou posicionar

contra os arrogantes adversários inimigos

nas sete saídas de nossas muralhas,

285 antes que um mensageiro com apressadas impetuosas

palavras chegue e elas nos inflamem com a urgência dos acontecimentos.

\section{Sai Etéocles}

\section{Canção coral ( $1^{\circ}$ estásimo)}

\section{Estrofe A}

\section{CORO}

(Em tom épico, correlacionando memória mítica - a guerra de Tróia - com cerco atual)

Vou obedecer. Mas o coração se sobressalta com medo

e bem junto de meu peito

290 as angústias acendem o pavor

pelo exército que cerca as muralhas, como por uma cobra

a tímida pomba teme muito ver emboscados

os filhotes de seu ninho.

295 Pois uns sobre as muralhas

armados da cabeça aos pés e em formação

avançam. 0 que vai acontecer?

Outros mais, contra já cercados

cidadãos arremessam

300 pedras denteadas.

Oh deuses de Zeus nascidos

com todos os meios a cidade e o povo

gerado por Cadmo protejam!

\section{Antístrofe A}

Qual lugar do mundo é mais fértil

305 que este, para que a castiguem, aos inimigos abandonando esta terra cheia de vigor e a fonte de Dirce, água mais nutritiva

310 de se beber, dada por Posídon, que faz tremer a terra, 
e os filhos de Tétis?

Então, oh deuses protetores

da cidade, sobre os que estão

fora dos muros uma covardia

fatal, um pânico delirante

315 lancem, e conquistem

a glória frente a estes para a cidade!

Permaneçam nossos defensores

em Tebas, aqui bem assentados,

320 por nossas suplicantes clamores!

\section{Estrofe B}

\section{(retorno à inquietação presente)}

Pois digno de lástima é que esta memorável cidade

seja tão logo lançada no Hades, despojo subjulgado pela lança, reduzida à cinzas,

325 devastada vergonhosamente pelos homens argivos com auxílio divino,

e que as mulheres cativas fossem arrastadas

(gritos de dor, foco no sofrimento feminino) EÉ, novas ou velhas,

tal como os cavalos pelas crinas, as vestes

rasgadas enquanto lutavam, e que se esgote

330 em prantos a cidade

e os cativos arruinados em meio à confusão de gritos.

Tenho receio da desgraça que pode acontecer.

\section{Antístrofe B}

É lamentável que jovens virgens antes dos ritos de casamentos tenham que trocar 335 sua casa por um caminho odioso.

Declaro que sem dúvida os mortos tiveram melhor fim que estas.

Pois, quando uma cidade é subjulgada (ampliação do foco ) EÉ seus males não tem seu fim. 3400 inimigo aprisiona uns e a outros

mata. Incendeia tudo. E a fumaça

deixa imunda a cidade inteira.

E Ares, que subjulga os homens, agita seus ventos furioso, violando o que se venera.

\section{Estrofe C}

0 tumulto ecoa pela cidade. Em torno dos muros estende-se

346 a armadilha. Com a lança um homem mata outro homem.

Os choros ensangüentados

350 dos bebês de colo

que ainda mamam ressoam.

Em toda parte o rapto se irmana ao rapto.

Um saqueador com outro saqueador se encontra

e como quantidade chama quantidade

cada cúmplice quer possuir

355 nem menos nem o mesmo que deseja.

0 que imaginar acerca disso?

\section{Antístrofe C}

Toda espécie de fruto é jogada ao chão

e aguda aflição atinge

os trabalhadores da casa.

360 Para a massa confusamente

as dádivas da Terra inúteis

como ondas se avolumam .

As cativas têm novos sofrimentos,

desgraçada cama de prisão

365 que o soldado vai prover.

Aos inimigos vitoriosos

noite após noite vão servir,

afligindo-se em súplicas cheias de lágrimas.

(Anúncio de personagens vindo das saídas laterais opostas. Entradas simultâneas, simétricas e divergentes de Etéocles e do Mensageiro.)

- Aquele espião, como parece a mim, amigas, 370 traz novas informações do exército inimigo Vem depressa repuxando os freios dos animais de seu carro.

\section{Entra o mensageiro}

- Chega também ele, o filho de Édipo,

para prontamente inteirar-se do relato do mensageiro.

Em sua pressa, o rei mal completa os passos. 


\section{Entra Etéocles}

\section{MENSAGEIRO}

375 Eu poderia relatar com clareza acerca dos planos dos inimigos

de modo a dizer quem foi sorteado para cada um de nossos portais.

Tideu desde agora ruge feito animal diante do porta

Proitide, mas o Adivinho não permite que ele atravesse

o rio Ismeno. Pois os sacrifícios não seriam favorecidos.

380 E Tideu, fora de si , cheio de desejo por lutar, grita e geme como uma serpente ao sol do meio-dia, e insulta e injuria o sábio adivinho filho de 0icles:

“ você balança o rabo covardemente para a luta e para a morte".

Dizendo isso, agita as três plumas negras

385 de seu capacete, e sobre seu escudo sinos de bronze ressoam o pavor.

Este escudo tem soberbo brasão modelado: um céu incendiado de estrelas .

E a lua cheia, bem no meio do escudo,

390 brilha radiosamente, senhora dos astros, olho da noite.

Tomado desta insolência argiva,

chora junto às margens do rio, querendo lutar,

como o cavalo, que relinchando sobre o freio, espera

o toque da batalha, e, esperando, agita-se por inteiro.

3950 que poderá se defrontar com ele? Quem, ao cair da barreira,

poderá assegurar o portal de Proitos?

\section{ETÉOCLES}

0s enfeites na armadura de um homem não me metem medo,

e muito menos uns símbolos podem me matar.

Nem sinos e nem plumas ferem sem a espada.

400 E essa tal noite declarada no escudo

com estrelas resplandecentes que tomam conta do céu

rapidamente essa loucura vai se transformar em profecia.

Pois se a noite cai sobre os olhos dos mortos então esse brasão presunçoso
405 fica justamente bem nomeado:

contra si mesmo profetizou tamanha desmesura.

Eu, contra Tideu, destaco o fiel filho de Astaco

para assegurar nosso portal,

muito bem nascido e que venera o trono

410 da Honra e detesta as palavras de soberba.

Não é dado ao vício, nem achegado à covardia.

Descende dos homens nascidos do dente do dragão,

poupados por Ares, de Melanipo, verdadeiro cidadão

tebano. Ares vai decidir a sorte do combate.

415 Mas Justiça, de mesmo sangue seu, realmente agora envia

este homem para afastar as lanças inimigas dos filhos dessa terra.

CORO

\section{Estrofe A}

(canto de contraponto às falas, focando sobre o próprio coro)

Que os deuses possam favorecer

o nosso campeão, pois ele se lança

em justa razão a lutar pela cidade: mas me apavoro

420 ao contemplar os corpos ensangüentados, caídos em desgraça

por causa de seus queridos!

\section{MENSAGEIRO}

Que os deuses possam favorecer teus planos!

Por outro lado, Capaneu foi sorteado para o portal Electra.

Esse outro gigante, gaba-se mais que

425 o primeiro, gloriando-se mais que um homem poderia pensar.

Fala que vai saquear, querendo deus

ou não, a cidade, mesmo que a cólera

de Zeus se abata sobre ele.

0 brilho e a luz dos raios celestes

430 compara com o sol no calor do meio dia.

Seu brasão é um homem nu portando fogo,

uma tocha flamejante em suas mãos como arma,

e que em letras douradas proclama: "Vou queimar a cidade".

435 Contra esse homem - envia algum... - quem poderá se opor? 
Quem vai poder suportar o homem com suas palavras?

\section{ETÉOCLES}

Tais palavras geraram para nós vantagem sobre vantagem!

Seguramente dos pensamentos arrogantes dos mortais

a língua se torna verídico acusador .

440 Capaneu faz promessas e se prepara para agir.

Exercitando sua boca em desonrar os deuses,

sendo mortal se engrandece lançando para o céu contra Zeus

orgulhosas e sonoras palavras.

Mas estou convencido de que, com justiça, sobre ele vai

445 sobrevir o raio flamejante incomparavelmente maior

que o brilho do Sol no calor do meio dia.

Apesar de seu falatório sem fim, contra ele designo um homem mesmo, com vontade ardente e pronta, o poderoso Polifontes, seguro sentinela avançado, 450 que vai sob o cuidado de Ártemis e de outros deuses.

Diga qual outro foi sorteado para o outro portal.

CORO

\section{Antístrofe A}

Morra aquele que faz tamanhas imprecações contra a cidade,

e uma flecha como raio possa atingi-lo

antes que invada minha casa e de meus aposentos 455 virginais, com arrogante lança, me expulse!

\section{MENSAGEIRO}

Vou dizer. No terceiro sorteio terceiro foi Etéoclo que apartando capacetes de bronze,

460 ergueu sua tropa para atacar portal Neís.

Com as rédeas faz os cavalos dar voltas bufando querendo saltar sobre as portas.

E as focinheiras assobiam uma melodia bárbara repletas que estão do hálito de suas narinas gabolas.
465 A aparência do escudo foi modelada sem modéstia.

Um soldado que sobe os degraus de uma escada avança sobre o muro inimigo querendo destruir tudo.

E essa figura fala através das letras escritas que nem Ares poderia atacar essas muralhas.

470 Contra este homem envia alguém capaz de impedir que a cidade caia em jugo de escravidão.

\section{ETÉOCLES}

Envio com segurança quem se gaba por seus braços,

Megareu, semente de Creonte, de linhagem espartana.

475 Pois vociferando os violentos relinchos dos cavalos

não ficaria com medo do ruído, afastando-se das portas.

Mesmo agonizando, iria cumprir com a terra que o nutriu ,

subjugando os dois guerreiros e a cidade do escudo como despojos de glória que ornariam a casa de seu pai.

480 Não invejo esses que, segundo teu relato, tanto se vangloriam.

CORO

\section{Estrofe B}

Suplico que você vença, (exclamação de confiança)

IÓ

defensor de minha casa, e derrote os inimigos!

Esses, fora de si, pronunciam contra a cidade palavras presunçosas. Que então agora

4855 Zeus retribua com ira a ira que contemplou!

\section{MENSAGEIRO}

0 quarto aos berros se aproxima da vizinha Porta de Atenas Onca,

a figura e a gigantesca forma de Hipomedonte, Ao ver girar a órbita inteira da circunferência 490 do escudo tremi de medo, não posso negar.

Aquele que fez o brasão não realizou coisa de pouco valor

pois acrescentou seu trabalho ao escudo:

um Tifeu lançando vapor escuro de sua boca 
inflamada pelo fulgor variado das chamas,

495 enquanto serpentes entrelaçadas estão fixas ao longo do fundo côncavo da circunferência.

Ele mesmo clama por guerra, tomado por Ares, como delirantes bacantes em luta fazendo visível o pavor.

É preciso estar atento aos planos desse homem. 500 Fobo desde já comemora diante dos portais.

\section{ETÉOCLES}

Inicialmente, a Palas Onca que, próxima à cidade, se avizinha aos portais, tem inimizade à desmesura humana,

e irá destruir os filhos deles como uma cruel serpente.

E Hipérbio, fiel filho de Enope,

505 o homem escolhido contra esse homem, pretende

conhecer seu destino quando acaso for preciso.

Nem seu aspecto, nem seu coração nem sua armadura

comportam reprovação. Hermes conduziu-o apropriadamente.

Pois quando o homem e seu inimigo se confrontam,

510 defrontam-se as inimigas divindades

no escudo. Se o outro tem no escudo o cospe-fogo Tifeu,

no de Hipérbio está Zeus em pé com um feixe de raios nas mãos,

o que com certeza traz sobre si o favor da divindade.

515 Somos os vencedores, eles, os derrotados,

se Zeus prevalecer na luta contra Tifeu.

Por meio de Hipérbio contra a voz do brasão,

520 Zeus poderá nos livrar, como seu escudo acaso mostrou.

CORO

\section{Antístrofe B}

Acredito que possuindo no escudo os repulsivos corpos dos adversários aos deuses, imagem odiada tanto pelos mortais

quanto pelos deuses imortais,

525 terá o crânio despedaçado frente ao portal!

\section{MENSAGEIRO}

Que seja assim! Relato então o quinto que está postado

diante do quinto portal, o de Bóreas,

em frente da tumba de Anfion, filho de Zeus.

Ele jura por suas flechas, as quais venera mais

530 que os deuses ou seus próprios olhos ainda,

que vai saquear a cidade cadméia, mesmo

contra Zeus. Isso fala esse filho de uma mulher das montanhas,

belo rapaz, jovem menino-homem,

no qual avança pelo rosto a penugem

535 da adolescência, crescendo em tufos espessos.

Mas feroz aproxima-se, nada tendo das virgens

que ele traz o nome, com o coração e olhos terríveis.

Não é sem se vangloriar que se apresenta diante dos portais.

Pois, para afronta da cidade, no escudo de bronze,

540 defesa envolta do corpo, agita brandindo a

Esfinge devoradora de carne crua, fixada

com pregos, corpo que brilha, em relevo.

Um homem, um cadmeu ela traz sobre pés ,

para lançar os dardos que puder contra ele.

545 Não vindo com a aparência de quem vem para apreçar a luta,

nem para deixar de fazer honra ao longo caminho percorrido,

eis Partenopeu, o Acadiano. Esse homem

é um meteco, saldando suas dívidas com Argos que bem o nutriu,

ameaça terrivelmente nossas muralhas, dizendo que nem deus pode com ele.

\section{ETÉOCLES}

550 Que eles possam receber dos deuses o que seus pensamentos

e o impiedoso jorro de suas palavras intencionam!

0 que seria um completo e terrível aniquilamento.

E para esse, o Acadiano, do qual você falou,

eis um homem sem vã gloria, mãos que sabem o que deve ser feito,

555 Áctor, irmão do nosso guerreiro anterior do qual já falamos.

Ele não vai permitir que a língua sem ações

se alastre depressa e aumente as angústias portais adentro, 
560 nem vai deixar que, vindo de fora, adentre a fera da mais

odiosa mordida. Aos que a trazem vai infligir danos

lamentáveis que antes iriam recair sobre a cidade com terrivel fulgor.

Queiram os deuses que eu possa estar dizendo a verdade.

CORO

\section{Estrofe C}

As palavras repercutem em meu peito, os cabelos transidos se trançam

565 ao ouvir as altissonantes

arrogâncias dos homens impiedosos. Tomara

pelos deuses que eles possam ser destruídos da terra!

\section{MENSAGEIRO}

Passo ao sexto homem, o mais sábio de todos, bravo no combate e grande profeta, o poderoso Anfiarau.

570 Postado diante do Portal Homolóides, ele recrimina bastante o poderoso Tideu,

“Assassino! Pestilência da cidade!

Por Argos o guia maior de males!

Arauto da Erínia! Servo de Fobo!

575 Conselheiro de Adrasto em todas essas infelicidades !"

Depois, em direção de teu irmão olha

o poderoso Polinices, nome que aterra,

e duas vezes chama, medindo enfim as partes do nome agourento

fala e essas palavras saem de sua boca:

580 “que obra tão cara aos deuses

gloriosa de se ouvir e de ser comentada pelos que vierem depois,

seria devastar a cidade de seus pais e os templos de sua terra, invadindo-a com um exército estrangeiro!

Que demanda legal poderia extinguir as fontes maternais?

$585 \mathrm{E}$ a terra do pai, conquistada pelo teu esforço com lanças,

como vai se tornar aliada de teus propósitos?
Eu mesmo agora vou fazer essa terra mais abundante adivinho oculto na terra inimiga.

Vamos, ao combate! Não espero morte sem honra!" 590 Isso falava o adivinho brandindo imperturbável o escudo de bronze maciço. Nenhum brasão havia sobre a orbe.

Pois não quer parecer, mas ser considerado excelente na guerra,

cultivando seu coração nos férteis campos onde germinam as valorosas intenções.

595 Contra esse agradecerei se enviar adversários tanto sábios

quanto honrados. Terrível é aquele que venera os deuses!

\section{ETÉOCLES}

FÊU Ah desgraça! Entre os mortais qual presságio reúne

um homem justo com os que são mais ímpios que eles mesmos!

Em toda atividade nada é pior que má

600 companhia, colher frutos que não se esperam.

Tal qual um homem piedoso que embarcando

com marinheiros que ardem de desejo por cometer maldades

e perece com essa raça de homens odiada pelos deuses;

ou como um justo que se associa com cidadãos

605 hostis aos estrangeiros e esquecidos pelos deuses

e injustamente é apanhado na mesma rede acaba subjugado com punição divina, açoite comum a todos.

Do mesmo modo o adivinho, dito filho de 0icles, homem prudente, justo, honrado, piedoso,

610 grande profeta, acompanhado de homens mal-intencionados, de linguagem temerária e pensamentos de violência dirigem- se em caravana para onde o retorno é longo se deus quiser arrastar para baixo.

Me parece que ele não vai atacar as portas,

615 não que esteja abatido ou em covarde audácia, mas sabe que deve morrer na guerra se os oráculos de Lóxias dão fruto.

Mesmo assim, frente a ele vamos contrapor um homem, 
o poderoso Lástenes, porteiro hostil a estrangeiros,

620 o espírito de ancião, corpo no vigor da juventude,

Seus olhos são ágeis e com o braço não se demora em atingir

pela lança o flanco inimigo não coberto pelo escudo.

625 A possibilidade dos mortais serem bem sucedidos é um dom divino.

\section{Antístrofe C}

CORO

Que os deuses ouçam nossas justas súplicas

e as satisfaçam: possa a cidade ser bem sucedida, e que façam voltar para a terra dos

invasores os males da guerra! Que fora das muralhas 630 lance Zeus seus raios e os mate!

\section{MENSAGEIRO}

Agora vou falar do sétimo homem está diante do sétimo

portal, o teu próprio irmão, que lança contra a cidade

suas preces e imprecações jurando que,

após escalar as muralhas e ser proclamado rei sobre a terra,

635 e entoar com frenético alarido a canção da conquista,

contigo vai lutar, matando e morrendo junto de ti ou te deixando vivo, a pagar com banimento aquilo que de igual modo o desonrou com exílio.

Isso clama aos berros e os deuses ancestrais

640 tutelares da terra paterna invoca para que favoreçam

completamente as súplicas do poderoso Polinices.

Ele traz um escudo redondo recentemente forjado,

com um duplo emblema fixado com arte:

um guerreiro dourado de ouro, ao que parece, avança

645 conduzido com por uma mulher de aspecto simples.

Ela reivindica ser Justiça, como as letras

anunciam: "Eu reconduzirei este homem para que

retome a cidade e a convivência com a casa paterna."
Tais são as suas invencionices.

650 Não reprove meu relato diante dos homens.

$\mathrm{E}$, tendo conhecido, dirija tu mesmo o curso da cidade.

\section{Sai o espião}

\section{ETÉOCLES}

Ah desgraçada família minha gerada por Édipo,

Ah enlouquecida e muito odiada pelos deuses!

655 (lamenta-se) Ah desgraça, ÓIMOI , agora é certo que as maldições paternas foram consumadas!

Mas convém nem chorar nem se queixar,

para que não sejam geradas lamentações impossíveis de suportar.

Realmente bem nomeado, o dito Polinices;

breve nós saberemos onde vai se cumprir o emblema,

660 se ele vai retornar mesmo de acordo com as letras de ouro sobre

o escudo, explosão torrencial de um coração desvairado.

Mas se a Justiça, virgem filha de Zeus estiver presente

nos atos e na mente dele, poderia acontecer como quer.

Mas nunca, nem ao emergir da escuridão do ventre materno,

665 nem na infância, nem na adolescência ainda,

nem quando se amontoava em seu queixo tufos de barba

a Justiça olhou em seu favor e o considerou digno.

E muito menos penso eu que ele pode encontrar apoio

enquanto está em processo de devastação da terra de seu pai.

670 E com toda certeza a Justiça poderia ser completamente infiel

com seu nome unindo-se a um homem de coração que a tudo se atreve.

É nisso que eu acredito e eu mesmo vou me colocar diante dele. Justamente, qual outro seria melhor? Vou por frente a frente senhor contra senhor e irmão contra irmão,

675 inimigo contra inimigo. Traga imediatamente minha armadura, abrigo contra lanças e flechas! 
(fala)

Oh mais querido dos homens, filho de Édipo, não se torne

da mesma natureza que ele, de renomada maldade.

Muitos homens de Tebas vão cair nas mãos

680 dos argivos, mas é sangue que pode ser purificado.

Entretanto, a morte de dois irmãos em mútuo assassinato

é mancha que não se pode esquecer.

\section{ETÉOCLES}

Se alguém suporta algum mal, deve ser sem desonra. Pois só há proveito na morte.

685 Ninguém vai falar da glória de males desonrosos.

Diálogo entre canto do coro e fala de Etéocles (epirrema).

(formação estrófica) Estrofe A

CORO

0 que deseja, filho?

Não deixe que os enganos do furor da guerra dominem teu coração. Rejeite desde o início a paixão do mal.

\section{ETÉOCLES}

Já que seguramente a divindade com urgência faz irromper os acontecimentos,

690 que logo, num ímpeto, lance para sua sorte, a onda do Cocito,

toda a raça de Laio odiada por Fobo.

\section{Antístrofe A}

CORO

A mordida feroz

do desejo te arrasta a consumar, apesar dos frutos amargos, matança de homens

cujo sangue é proibido derramar.

ETÉOCLES

695 É que a odiosa Maldição do querido pai, com olhos ressequidos e sem lágrimas, se aproxima

dizendo que mais honra há em morrer primeiro.
CORO

Mas resiste ao que te arrasta. Ninguém vai te chamar de covarde por querer viver. A negra 700 Erínia vai sair desta casa quando os deuses receberem de tuas mãos sacrifícios.

\section{ETÉOCLES}

Aos deuses agora de algum modo parece que temos sido negligentes,

e não se maravilham prazerosamente com nossa destruição?

Por que então ainda seria possível abanar o rabo diante desse destino de ruína?

\section{Antístrofe B}

CORO

Hoje isso ainda está junto de ti, mas o deus

706 poderá alterar seus desígnios algum tempo depois

como igualmente podem vir mudados ventos

mais amenos. Mas no momento o deus é fúria.

\section{ETÉOCLES}

Pois os deuses se enfureceram completamente com as juras de Édipo.

710 Demasiado verdadeiras foram as visões que apareceram

nos sonhos, divisoras das propriedades herdadas.

Debate e confrontação verso a verso (esticomitia)

CORO

Continuem tentando, mulheres, embora não gostando disso.

ETÉOCLES

Vocês poderiam chegar a uma conclusão mas sem se alongar.

CORO

Não tome este caminho para a sétima porta.

ETÉOCLES

715 Não vai enfraquecer minha vontade com palavras.

CORO

Certamente uma sorte melhor, mesmo covarde, é honra para a divindade. 


\section{ETÉOCLES}

Um soldado não deve admitir esta afirmativa.

CORO

Mas você quer colher o sangue de teu próprio irmão? ETÉOCLES

Não se pode escapar do males dados pelos deuses.

Sai Etéocles

Canção coral ( $2^{\circ}$ estásimo)

\section{Estrofe A}

CORO

Estremeço de terror com a deusa destruidora de lares,

721 divindade diferentes de outras divindades, certeira profeta de males,

Erínia invocada pelo pai

que vêm cumprir as iradas

725 maldições das loucuras de Édipo.

Essa discórdia pode determinar a destruição dos filhos.

\section{Antístrofe A}

E aquele que lança as sortes, o estrangeiro

Cálibe, vindo da Cítia,

severo distribuidor de

730 riquezas, o selvagem Ferro,

tendo sorteado quem habitar a terra,

decidiu que os mortos não tomarão

posse de seus vastos campos.

\section{Estrofe B}

Depois de matarem um ao outro,

735 em assassínio mútuo morrendo, e o pó da terra sorver o negro jorro de sangue deles,

quem vai poder oferecer sacrifícios de purificação?

Quem vai poder lavar seus corpos? Ah,

740 novas aflições da casa que se ajuntam

às aflições antigas!

\section{Antístrofe B}

Pois relato a antiga transgressão depressa punida, e que pela

745 terceira geração permanece, desde que Laio voltou-se contra Apolo que disse três vezes

em oráculos da Pítia no centro

da terra que se ele morresse sem filhos

poderia salvar a cidade,

\section{Estrofe C}

e vencido por um louco impulso,

751 destinou sua própria morte,

o parricida Édipo,

que o sagrado campo de sua mãe

semeou onde foi nutrido

755 e sofreu uma sangrenta

colheita. Um delírio une

os consortes em loucura.

Antístrofe C

Um mar de males arrasta suas ondas;

se uma cai, outra se ergue três vezes

mais forte, e estrondeia em volta

760 da popa da cidade.

Entre essa força e nós

resiste a espessura de uma frágil muralha.

Tenho receio de ver a cidade

765 destruída com seus reis.

\section{Estrofe D}

Pois eis que essas duras reconciliações consumam as maldições ditas no passado. 0s desastres acontecidos permanecem.

770 Foi lançada proa abaixo

a audácia dos homens em

prosperar demasiadamente.

\section{Antístrofe D}

Pois qual desses homens alguma vez não foi visto com admiração

pelos deuses protetores da cidade

e pela muito freqüentada assembléia dos mortais

775 quanto o venerado Édipo

que libertou a terra

do monstro devorador de homens? 


\section{Estrofe E}

E depois que tomou consciência

780 do infeliz casamento,

afligiu-se dolorosamente,

e com o coração cheio de ódio

consumou um duplo mal:

com a mão que matou o pai

fere os olhos que preferia mais que a seus filhos,

\section{Antístrofe E}

e contra os filhos, irado com seus

786 infelizes cuidados, (reação interjeitiva) AIAÍ lançou

maldições em cruel linguagem:

somente com as mãos em ferros

terão parte alguma vez nas propriedades.

790 Agora eu tremo de medo que a

ágil Erínia venha dar um fim em tudo.

\section{Entra o mensageiro}

\section{MENSAGEIRO}

Coragem, mulheres filhas de mulheres,

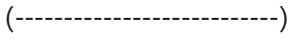

a cidade escapou do jugo de escravidão.

As palavras de glória dos homens fortes caíram por terra.

795 A cidade tanto mostra-se em bom tempo,

quanto não recebe os golpes das muitas ondas do mar.

As muralhas estão seguras, e para assegurar os portais

designamos defensores aptos a lutar por elas.

800 Deu-se o melhor possível nas seis portas.

Mas na sétima, o venerável Apolo, senhor

que comanda a sétima porta, determinou-se, sobre os filhos de Édipo,

a consumar as antigas loucuras de Laio.

CORO

Qual é a nova e completa angustiante situação da cidade?

MENSAGEIRO

A cidade está salva, mas os reis irmãos,
805 os homens foram mortos, assassinados por suas próprias mãos.

CORO

Qual deles? 0 que você está dizendo? Estou fora de mim, apavorada com essas palavras .

MENSAGEIRO

Tenha bom senso e ouve: os filhos de Édipo...

CORO

Ah, desgraçado sou, profeta de males!

MENSAGEIRO

... sem dúvida alguma estão abatidos no pó da terra CORO

810 Estão na terra então? Mesmo sendo duro de suportar, relate.

MENSAGEIRO

Com as mãos os irmãos mataram um ao outro.

De forma que o destino comum de ambos foi comum,

o que fez perecer realmente essa linhagem desafortunada.

Por isso, há razões tanto para chorar quanto para rir. 815 A cidade foi bem sucedida, mas os líderes,

os dois comandantes partilharam

seus bens com o aço forjado na Cítia.

Eles terão posse na terra que tomarem da sepultura,

arrastados para lá desgraçadamente pelos votos de um pai.

820 A cidade está salva, mas de ambos os reis irmãos

a terra bebeu o sangue derramado no mútuo assassinato.

\section{Sai o mensageiro}

Começo da lamentação fúnebre.

CORO

(hesitação) Oh grande Zeus e divindades protetoras da cidade, vocês que até hoje as muralhas de Tebas defendem,

825 devo me alegrar e gritar em triunfo pela preservação da cidade intacta, ou lamentar nossos líderes guerreiros desgraçados, desafortunados e sem filhos, que de fato corretamente nomeados 830 homens de muita luta destruídos foram por suas intenções impiedosas ? 


\section{Estrofe A}

(Ordenação estrófica)

Ah negra e fatal

maldição de Édipo!

Um calafrio de terror se abate sobre meu pobre coração.

835 Fiz uma canção para o enterro,

em delírio como uma bacante,

ao ouvir o sangue dos corpos mortos por destino infeliz

gotejando. Foi de mal agouro

esse concerto de lanças.

\section{Antístrofe A}

Cumpriu-se a maldição

841 do pai, a palavra votiva.

$E$ as desobediências de Laio

se alongam.

E ambos me afligem pela cidade.

Os divinos decretos não perdem seu vigor.

845 IÓ lamentáveis guerreiros! Realiza-se sobre vocês

algo difícil de se acreditar. Eis que chegam lamentáveis

sofrimentos e não apenas palavras.

(Entram os corpos dos mortos. Segue-se preludio lírico à completa lamentação que será realizada)

Os eventos são evidentes. A palavra do mensageiro é clara.

Dores duplas, duplos desastres.

850 Assassinos de iguais, duas mortes, a aflição chega ao fim. 0 que vou dizer?

Que outra coisa senão sofrimentos seguidos de sofrimentos são próprios dessa casa?

Mas, oh amigas, naveguem sob o vento das lamentações

e lancem sobre a cabeça com as mãos rápidos golpes,

855 golpes sempre causados pelo negro barco

que através do Aqueronte passa

para terra invisível onde Apolo não anda,
860 terra sem sol que recebe todos os homens.

Divisão do coro em dois semicoros e estruturação estrofico-responsiva para lamentar os dois mortos.

\section{Estrofe A}

\section{SEMICORO A}

876 (Interjeições de lamento) Ió Ió, infelizes, infiéis amigos e incansáveis em males, para tristeza de vocês

em vão tomaram a casa do pai com a espada.

\section{SEMICORO B}

(em resposta) Para tristeza deles realmente encontraram

880 tristes mortes no ultraje da casa.

\section{Antistrofe A}

SEMICORO A

(Interjeições de lamento) IÓ IÓ destruidores de lares e monarcas colhidos desastrosamente:

agora vocês foram reconciliados

pela espada.

\section{SEMICORO B}

885 Mas na verdade foi mesmo a soberana Erínia do pai Édipo

que tudo realizou .

\section{Estrofe B}

\section{SEMICORO A}

Trespassados no flanco esquerdo, realmente trespassados,

890 os lados gerados do mesmo ventre.

(lamento)AIAI meus senhores

(lamento) AIAI malditas mortes por mortes. 


\section{SEMICORO B}

895 Com certeza, como você disse, eles foram feridos,

um golpe para os corpos e para as casas,

resultando em ardor sem voz

proferido pela maldição do pai

que foi partilhado sem discórdias.

\section{Antístrofe B}

\section{SEMICORO A}

0 lamento espalha-se pela cidade.

901 Lamentam as muralhas, lamenta

a terra que ama seus filhos.

A luta desses infelizes homens

905 se completa em morte.

\section{SEMICORO B}

Em sua apressada ira dividiram entre si

suas posses de tal modo que partes iguais receberam.

0 mediador não é capaz

de censurar os irmãos,

910 nem Ares é complacente.

\section{Estrofe C}

\section{SEMICORO A}

Então os que receberam golpes de ferro

e que entre ferros agora restam

- alguém talvez possa dizer-

partilham a tumba do pai.

\section{SEMICORO B}

915 Afligindo-se muito pelos da casa,

envia mortal gemido,

infeliz e autoflagelante ,

triste e sem vida,

vertendo verdadeiramente lágrimas do coração

920 que definha lamentando esses dois senhores.

\section{Antístrofe C}

\section{SEMICORO A}

Pode-se afirmar a respeito dos combatentes que foram bem sucedidos tanto com os cidadãos quanto com as fileiras dos inimigos

925 em abundante banquete de morte.

\section{SEMICORO B}

Infelizes deles que nasceram

da mais desafortunada de todas as mulheres, que foi chamada para gerar filhos.

Isso se deu após ela tornar o próprio filho seu marido. Então estes

930 de mesma origem encontraram seu fim ao se matarem mutuamente por suas mãos.

\section{Estrofe D}

\section{SEMICORO A}

Realmente de mesma origem e totalmente destruídos

por feridas cruéis

935 em furiosa ira de lutas fatais.

\section{SEMICORO B}

0 ódio cessou; suas vidas

encharcam de sangue morto

940 a terra. Realmente agora têm o mesmo sangue. 0 cruel estrangeiro que vem do mar, árbitro da lutas, salta do fogo, aço aguçado, cruel e maléfico distribuidor 945 das riquezas, Ares, que as maldições do pai realiza hoje.

\section{Antístrofe D}

SEMICORO A

Tiveram sua parte na sorte, oh infelizes, 
sofrendo o que os deuses ofertaram.

950 Debaixo de seus corpos o abismo da terra vai ser a riqueza deles.

\section{SEMICORO B}

(reação interjeitiva) Ió eles adornaram sua raça

com muitos sofrimentos.

Finalmente as Malditas soltam

o agudo clamor de seu triunfo: a família

955 foi lançada em todas as direções.

0 troféu da Ruína encontra-se nas portas

onde lutaram e a ambos

960 a poderosa divindade abateu.

Início de nova dinâmica coral. Cada verso é dividido entre as alternâncias dos dois coros em lamento responsivo. 0 s líderes de coro focalizam os mortos: - coro A com foco em Etéocles, coro B, em Polinices. Dessa maneira há um deslocamento do lamento responsivo performado para uma apropriação paródica do confronto entre os dois irmãos mortos. A terrivel morte dos irmãos é reelaborada em cena.

\section{Prelúdio e estrofe para marcar nova dinâmica}

SEMICORO A Você feriu e foi ferido. SEMICORO B Morreu matando.

A- Pela lança você matou. B- Pela espada você morreu.

A- Miseráveis esforços. B- Miseráveis sofrimentos.

A- Deixado morto. B- Assassinado.

A- Que venha o lamento. B- Que corram as lágrimas.

\section{Arranjo estrófico}

\section{Estrofe A}

A - (lamento) EÉ B-(lamento) EÉ

A - Meu coração se transtorna com os lamentos.

$B$ - E o meu geme dentro de mim.

A - (reação interjeitiva) IÓ IÓ Triste de ti, totalmente deplorável. B- E por sua vez, também você, completamente desgraçado.

A - Por quem era mais próximo você foi morto. B- E quem era mais próximo você matou.
A- Dupla linguagem. B Redobrada visão.

A- Tais aflições são próximas a eles. B- Irmãos nos sofrimentos irmãos.

CORO

(reação interjeitiva em refrão) IÓ Destino, desgraçada dadivosa de males,

senhora do espírito de Édipo,

negra Erínia, realmente grande é teu poder.

\section{Antístrofe A}

A - (lamento) EÉ. B(lamento)EÉ.

A - Aflições duras de se ver... B- mostrou para mim vindo do exílio.

A - Não retornou quando matou B-Tendo chegado, perdeu a vida.

A - Perdeu mesmo. B- E dela ficou privado.

A - Desgraçada família. B- Desgraçada dor.

A - Infelizes lamentações entre iguais B- Abatidos em tríplice aflição.

A - Destruidora linguagem. B- Destruidora visão.

CORO

(refrão)

Ah Destino, desgraçada dadivosa de males, senhora do espírito de Édipo,

negra Erínia, realmente grande é teu poder.

ÉPODO

A - Provando você entendeu. B- compreendendo nem tão tarde.

A - Ao retornar do exílio para casa B- com a espada contra seu adversário.

A - (reação interjeitiva) IÓ pesares! B(reação interjeitiva) B IÓ males!

A - Para a casa. B- E para a terra.

A - E acima de todos para mim. B- E para mim mais que todos.

A - Ah, infelizes desgraças, senhor.

(..) rei Etéocles

A - IÓ maior de todas as desgraças! B-Ió homens tomados de divinos desvarios!

A - IÓ onde os enterraremos ? B IÓ onde serão mais honrados!

A-IÓ Deitados com as misérias do pai.

FIM 


\section{Bibliografia}

Edições - 0 . Hutchinson ( Oxford University Press, 1985) e M.L.West ( Teubner, 1998).

Traduções consultadas: Seven Against Thebes por A . Hechet e H. Bacon ( Oxford University, Press,1973), Os Sete contra Tebas por Donald Schüler( L\&PM,2003), e Ésquilo. Tragédias., por Jaa Torrano( Iluminuras/FAPESP, 2009.

\section{Livros e artigos:}

BACON, H. “The Shield of Eteocles" in SEGAL 1982:24-33. BRANDÃO, J. L. "Ver ouvir, interpretar: a propósito dos Sete contra Tebas de Ésquilo"in Clássica 2(1989): 70-87.

CONACHER, D.J. Aeschylus The Earlier Plays and Related Studies Toronto, University of Toronto Press, 1996.

DI BENEDETTO,V. e MEDDA, E. La tragedia sulla scena Torino, Einaudi, 1997.

EDINGER, H. Index Analyticus Graecitatis Aeschyleae Gerg Olms, 1981.

HERINGTON, J. Aeschylus Yale University Press, 1986.

HERINGTON, J. Poetry into drama: Early tragedy and the greek poetic University of Californi Press,1985.

JARCHO, V. "Die komposition der aischuleischen siben gegen theben"in PHILOLOGUS 131(1987)165-184.

KAIMIO, M. The Chorus of Greek Drama within the Light of the Person and Number Used Helsink, Societas Scientiarum Fennica, 1970.

KAIMIO, M. Characterization of Sound in Early Greek Literature Helsinki, Societas Scientiarum Fennica, 1977.

MOTA, M. Imaginação dramática e outros ensaios. Brasília, Texto\&Imagem, 1998

MOTA, M. A dramaturgia musical de Ésquilo. Investigações sobre composição, realização e recepção de ficções audiovisuais. Brasília: Editora UnB, 2008.

NAGY, G. Pindar's Homer The Lyric possession of na epic past The Johns Hopkins University Press, 1990.

NAGY, G. Poetry as performance. Homer and Beyond Cambridge University Press, 1996.
PERETTI, A . Epirrema e tragedia: studio sul dramma atico arcaico Florença, Felice Le Monnier Editore, 1939.

ROSENMEYER, T.s The Art of Aeschylus University of California Press, 1982.

SCOTT, W. C. Musical Design in Aeschean Theater University Press of New England, 1984.

SMETHURST, M. The artistry of Aeschylus and Zeami. Comparative study of Greek tragedy and Nô. Princeton, Princeton University Press,1989.

SOMMERSTEIN, A. Aeschyelan Tragedy Bari, Levante Editori, 1994.

SOMMERSTEIN, A . "Notes on Aeschylus 'Seven Against Thebes'"in Hermes 117 (1989):433-445.

TAPLIN, 0. The Stagecraft of Aeschylus 0xford University Press, 1977.

TAPLIN, 0. Greek Tragedy in Action Londres, Methen, 1978.

THALMANN, W. Dramatic Art in Aeschylus's Seven Against Thebes Yale University Press, 1978.

UNEÑA PRIETO, M.H.T.C, UREÑA PRIETO, J.M.T.C e PENA, $A$. N. Índice de nomes próprios gregos e latinos. Lisboa, Fundação Calouste Gulbenkian/INICT, 1995.

VERNANT, J.P e VIDAL-NAQUET , P. Mito e Tragédia na Grécia antiga. São Paulo, Perspectiva, 1999.(Essa edição brasileira reúne as duas coletâneas de textos publicadas em1972 e 1986).

VIDAL-NAQUET, P. “Os escudos dos Heróis. Ensaio sobre a cena central de 0 s Sete contra Tebas" in VERNANT, J-P. e VIDAL-NAQUET, P. 1999: 241-266.

WARTELLE, A. Histoire du texte d'Eschyle Paris, Belles Lettres, 1971.

WEST, M.L. Studies in Aeschylus. Sttutgart, Teubner, 1990.

WILES, D. Greek Theatre Performance Cambridge University Press, 2000.

WILES, D. Tragedy in Athens. Performance Space and Theatrical Meaning Cambridge University Press, 1997.

WILES, D. "Les sept contre Thèbes d'Escyle" in CGITA 6(1991)145-160.

WINNINGTON-INGRAM , R.P. Studies in Aeschylus Cambridge University Press, 1983. 